\title{
Aplikasi Bahan Amelioran \\ (Asam Humat; Lumpur IPAL Tambang Batu Bara) terhadap Pertumbuhan Tanaman Reklamasi pada Lahan Bekas Tambang Batu Bara
}

\author{
Syafrinaldi Adhiatma; Trisno Budi Susanto; Awaluddin Nurmiyanto dan Hudori \\ Jurusan Teknik Lingkungan, Fakultas Teknik Sipil dan Perencanaan, \\ Universitas Islam Indonesia
}

\begin{abstract}
Abstrak
Air limbah yang dihasilkan oleh PT Baradinamika Mudasukses (BDMS) merupakan lumpur yang bersifat koloid dan susah mengendap. Pemanfaatan lumpur kembali dalam proses reklamasi bekas lahan tambang batubara sebagai alternatif untuk mengangani permasalahan lumpur tersebut. Tujuan dari penelitian ini adalah untuk mengkaji pengaruh penambahan lumpur dan asam humat pada lahan bekas tambang batubara dengan tanaman reklamasi. Metode yang digunakan adalah Rancangan Acak Lengkap (RAL) dengan variasi media T1S1 (100\% tanah; 0\% lumpur), T2S2 (50\% tanah; 50\% lumpur), dan T3S3 (75\% tanah; 25\% lumpur) dengan variasi dosis asam humat H1 (Oml), H2 (7,5ml), dan H3 (15ml) dengan menggunakan tanaman Sengon (Paraserienthes falcataria) dan Akasia (Acacia mangium). Hasil dari penelitian ini menunjukan pada perlakuan T1S1 dan T2S2 dengan dosis 7,5ml (H2) pada kadar hara N-Total dan P-Tersedia sedangkan pada kadar hara K dan Ca pada perlakuan T2S2 dengan dosis $15 \mathrm{ml}$ (H3). Hasil pertumbuhan tinggi pada pada perlakuan T3S3 dengan dosis 7,5ml (H2) sebesar 16,1\% dengan hasil nilai uji statistik sebesar 4,0b pada tanaman sengon dan pada tanaman akasia mengalami peningkatan tinggi sebesar $18 \%$ dan nilai hasil uji statistik sebesar 3,75b. Hasil pertumbuhan daun pada tanaman sengon memiliki nilai sebesar 2,75a dan pada tanaman akasia sebesar 3,0a.
\end{abstract}

Kata kunci : Air Limbah, Lumpur, Asam Humat, Reklamasi

\section{PENDAHULUAN}

Aplikasi sistem penambangan pada kegiatan eksploitasi batubara di Indonesia pada umumnya menggunakan sistem terbuka. Penambangan sistem ini menyingkirkan seluruh lapisan tanah yang berada di atas deposit batubara. Hal ini akan menghilangkan lapisan top soil dan sub soil yang kaya bahan organik tanah akan menghambat proses-proses biologis dalam tanah sehingga proses-proses yang membantu pembentukan tanah (pedogenesis) dan pertumbuhan tanaman menjadi terganggu.

PT. Baradinamika Mudasukses (BDMS) salah satu perusahaan penambangan batubara yang menggunakan sistem terbuka sehingga dampak-dampak negatif yang ditimbulkan dapat merusak lingkungan jika tidak dikelola dengan baik. Salah satu dampak yang ditimbulkan adalah terbentuk air asam tambang (AAT). Untuk menanggulangi dampak negatif tersebut PT. BDMS membuat instalasi pengolahan air limbah (IPAL).

Air limbah yang dihasilkan oleh PT. BDMS berasal dari limpasan air hujan yang bercampur dengan tanah overburden (penutup) sehingga menjadi lumpur yang bersifat koloid dan susah mengendap. 
Sludge atau lumpur merupakan produk sampingan dari proses pengolahan air, hingga saat ini di buang di lahan kosong dan tidak dimanfaatkan kembali. Maka dari itu pemanfaatan lumpur kembali dalam proses reklamasi bekas lahan tambang batubara sebagai alternatif untuk mengangani permasalahan lumpur tersebut.

Adapun tujuan penelitian yang akan dilakukan adalah: 1) Mengkaji pemanfaatan lumpur instalasi pengolahan air limbah tambang batubara sebagai pengganti tanah top soil pada reklamasi lahan bekas tambang batubara. 2) Mengkaji pengaruh variasi campuran tanah, lumpur instalasi pengolahan air limbah tambang batubara dan asam humat terhadap sifat kimia tanah. 3) Mengkaji pertumbuhan tanaman reklamasi dengan mengukur tinggi tanaman, diameter tanaman, dan jumlah daun.

\section{METODE PENELITIAN}

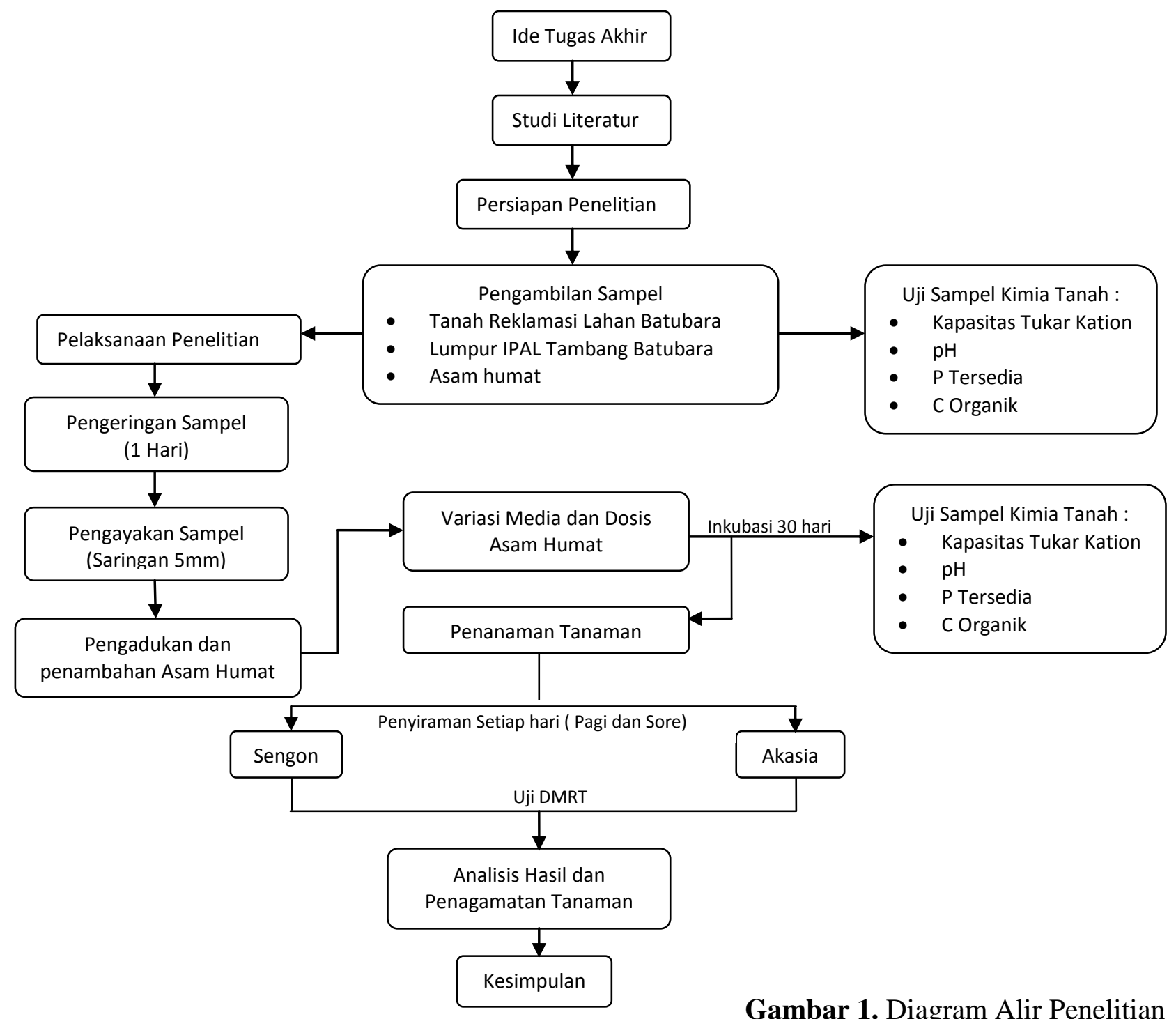


Pada penelitian ini dilakukan di rumah kaca Garden House Jalan Kaliurang KM 7 menggunakan Polybag ukuran $15 \mathrm{~cm} \times 15 \mathrm{~cm}$ dengan variasi media T1S1 (100\% tanah; 0\% lumpur), T2S2, (50\% tanah: 50\% lumpur), dan T3S3 (75\% tanah; 25\% lumpur) dengan dosis humat $\mathrm{H} 1$ (0ml), H2 (7,5ml), dan H3 (15ml) dengan menggunakan metode Rancangan Acak Lengkap (RAL) dengan rincian sebagai berikut : .

Tabel 1. Perlakuan Tanah, Sludge, dan Asam Humat

\begin{tabular}{|c|c|c|c|}
\hline \multicolumn{1}{|c|}{ Perlakuan } & $\mathbf{T}$ & $\mathbf{S}$ & $\mathbf{H}$ \\
\hline $\mathrm{T} 1+\mathrm{S} 1+\mathrm{H} 1$ & 100 & 0 & $0 \mathrm{ml}$ \\
\hline $\mathrm{T} 1+\mathrm{S} 1+\mathrm{H} 2$ & 100 & 0 & $7,5 \mathrm{ml}$ \\
\hline $\mathrm{T} 1+\mathrm{S} 1+\mathrm{H} 3$ & 100 & 0 & $15 \mathrm{ml}$ \\
\hline $\mathrm{T} 2+\mathrm{S} 2+\mathrm{H} 1$ & 50 & 50 & $0 \mathrm{ml}$ \\
\hline $\mathrm{T} 2+\mathrm{S} 2+\mathrm{H} 2$ & 50 & 50 & $7,5 \mathrm{ml}$ \\
\hline $\mathrm{T} 2+\mathrm{S} 2+\mathrm{H} 3$ & 50 & 50 & $15 \mathrm{ml}$ \\
\hline $\mathrm{T} 3+\mathrm{S} 3+\mathrm{H} 1$ & 75 & 25 & $0 \mathrm{ml}$ \\
\hline $\mathrm{T} 3+\mathrm{S} 3+\mathrm{H} 2$ & 75 & 25 & $7,5 \mathrm{ml}$ \\
\hline $\mathrm{T} 3+\mathrm{S} 3+\mathrm{H} 3$ & 75 & 25 & $15 \mathrm{ml}$ \\
\hline
\end{tabular}

Keterangan :

$\mathrm{T} \quad=$ Tanah

$\mathrm{S} \quad=$ Sludge

$\mathrm{H} \quad=$ Dosis Humat

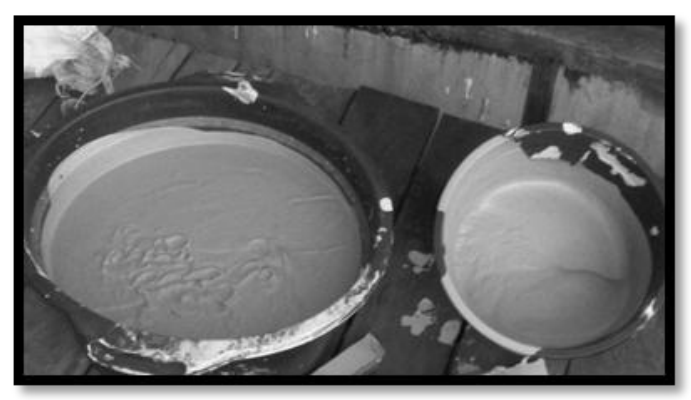

Gambar 2. Sampel lumpur IPAL PT.BDMS

Tanaman reklamasi yang digunakan adalah Sengon (Paraserienthes falcataria) dan Akasia (Acacia Mangium). Untuk mengetahui proses pertumbuhan tanaman, maka dilakukan pengamatan selama perumbuhan tanaman reklamasi berdasarkan indikator :

1. Pertumbuhan tinggi tanaman.

2. Diameter tanaman.

3. Jumlah daun tanaman. 


\section{HASIL DAN PEMBAHASAN}

\section{A. Pengaruh Bahan Amelioran terhadap Kadar Hara}

Tabel 2. Pengaruh Bahan Amelioran terhadap Kadar Hara N-Total

\begin{tabular}{|c|c|c|c|}
\hline \multirow{2}{*}{$\begin{array}{c}\text { Dosis } \\
\text { H (Asam Humat) }\end{array}$} & T1S1 & T2S2 & T3S3 \\
\cline { 2 - 4 } H1 & $0.085 \mathrm{a}$ & $0.11 \mathrm{bc}$ & $0.1 \mathrm{ab}$ \\
\hline H2 & $0.085 \mathrm{a}$ & $0.115 \mathrm{bc}$ & $0.1 \mathrm{ab}$ \\
\hline H3 & $0.085 \mathrm{a}$ & $0.12 \mathrm{a}$ & $0.105 \mathrm{bc}$ \\
\hline
\end{tabular}

Keterangan Angka yang diikuti oleh huruf yang sama pada kolom yang sama tidak berbeda nyata atau tidak signifikan menurut uji DMRT (taraf $\alpha=5 \%$ ). T1, T2, T3 = Tanah 100\%, 50\%, 75\%. S1,S2,S3 = Sludge 0\%,50\%,25\%. H1,H2,H3= Humat dengan dosis $0 \mathrm{ml}, 7,5 \mathrm{ml}, 15 \mathrm{ml}$.

Pada pengukuran awal konsentrasi N-Total termasuk sangat rendah. Pada perlakuan T1S1, T2S2, dan T3S3 dengan dosis $\mathrm{H} 1(0 \mathrm{ml}), \mathrm{H} 2(7,5 \mathrm{ml})$, dan $\mathrm{H} 3(15 \mathrm{ml})$ terdapat kenaikan dan penurunan konsentrasi yang dipengaruhi oleh bahan humat dan lumpur namun tidak signifikan. Penurunan konsentrasi N-Total pada perlakuan T1S1 dan T2S2 dengan dosis 0ml (H1) hal ini diduga karena pada perlakuan tersebut tidak ada pencampuran asam humat dan pada perlakuan T2S2 diduga dipengaruhi oleh konsentrasi daya hantar listrik pada lumpur Intalasi Pengolahan Air Limbah (IPAL) tambang batubara yang mengandung unsur-unsur mineral dan bahan koagulan yang dapat mempengaruhi kapasitas N-Total.

Peningkatan N-Total terjadi pada media tanam T1S1 dengan dosis 7,5ml (H2) dan 15ml (H3), T2S2 dengan dosis 7,5ml (H2) dan juga terjadi perlakuan dengan T3S3 dengan dosis $15 \mathrm{ml}(\mathrm{H} 3)$ dapat meningkatkan N-Total. Pengaruh penambahan kadar N-Total pada H2 dan H3 disebabkan bahan humat mempunyai kandungan $\mathrm{C}, \mathrm{N}$, dan $\mathrm{S}$ yang lebih tinggi dari dosis H1, Kadar asam humat berkisar antara 2-5\% (Tan, 1993).

Berdasarkan hasil uji laboratorium pada perlakuan T2S2 dengan dosis 7,5 ml (H2) mengalami peningkatan sebesar 75\% dan pada perlakuan T1S1 dengan dosis $15 \mathrm{ml}$ (H3) tidak ada perubahan. Namun pada perlakuan T1S1 dengan dosis 0 (nol) $\mathrm{ml}(\mathrm{H} 1)$ dan 7,5 ml (H2); T2S2 dengan dosis 0 (nol) $\mathrm{ml}(\mathrm{H} 1)$ dan $15 \mathrm{ml}(\mathrm{H} 3)$; T3S3 pada dosis 0 (nol) $\mathrm{ml}(\mathrm{H} 1), 7,5 \mathrm{ml}(\mathrm{H} 2)$, dan $15 \mathrm{ml}(\mathrm{H} 3)$ mengalami penurunan yang signifikan. Penurunan kadar hara P-Tersedia diduga karena $\mathrm{pH}$ tanah, bahan humat, dan lumpur yang tergolong bersifat asam. 
Tabel 3. Pengaruh Bahan Amelioran terhadap Kadar Hara P-Tersedia

\begin{tabular}{|c|c|c|c|}
\hline \multirow{2}{*}{ Dosis } & \multicolumn{3}{|c|}{ Variasi Media } \\
\cline { 2 - 4 } & T1S1 & T2S2 & T3S3 \\
\hline H1 & $1.55 \mathrm{a}$ & $0.4 \mathrm{a}$ & $0.8 \mathrm{a}$ \\
\hline H2 & $2 \mathrm{a}$ & $0.55 \mathrm{a}$ & $1.9 \mathrm{a}$ \\
\hline H3 & $4.4 \mathrm{a}$ & $1.6 \mathrm{a}$ & $4.6 \mathrm{a}$ \\
\hline
\end{tabular}

Keterangan Angka yang diikuti oleh huruf yang sama pada kolom yang sama tidak berbeda nyata atau tidak signifikan menurut uji DMRT (taraf $\alpha=5 \%$ ). T1, T2, T3 = Tanah 100\%, 50\%, 75\%. S1,S2,S3 = Lumpur 0\%,50\%,25\%. H1,H2,H3= Humat dengan dosis $0 \mathrm{ml}, 7,5 \mathrm{ml}, 15 \mathrm{ml}$.

Berdasarkan penelitian yang telah dilakukan diketahui kadar $\mathrm{pH}$ mengalami peningkatan meskipun tidak berpengaruh secara signifikan. Asam humat dengan dengan konsentrasi humic sebesar 20$30 \%$ dapat menurunkan kadar Al dalam tanah karena asam-asam organik dari bahan humat mampu mengikat unsur $\mathrm{Al}$ dan atau Fe sebagai senyawa kompleks atau terkhelat, sehingga $\mathrm{P}$ yang terikat $\mathrm{Al}$ dan Fe dapat tersedia. Sehingga dengan demikian dapat dikatakan bahwa kadar humic dan pH pada asam humat yang rendah tidak dapat meningkatkan $\mathrm{pH}$ yang mempengaruhi kadar hara P-Tersedia pada kondisi ini (Wibowo, 2011).

Tabel 4. Pengaruh Bahan Amelioran terhadap Parameter Kalium

\begin{tabular}{|c|c|c|c|}
\hline \multirow{2}{*}{ Dosis } & \multicolumn{3}{|c|}{ Variasi Media } \\
\cline { 2 - 4 } & T1S1 & T2S2 & T3S3 \\
\hline H1 & $0.13 \mathrm{a}$ & $0.115 \mathrm{a}$ & $0.11 \mathrm{a}$ \\
\hline H3 & $0.11 \mathrm{a}$ & $0.265 \mathrm{a}$ & $0.11 \mathrm{a}$ \\
\hline
\end{tabular}

Keterangan Angka yang diikuti oleh huruf yang sama pada kolom yang sama tidak berbeda nyata atau tidak signifikan menurut uji DMRT (taraf $\alpha=5 \%$ ). T1, T2, T3 = Tanah 100\%, 50\%, 75\%. S1,S2,S3 = Lumpur 0\%,50\%,25\%. H1,H2,H3= Humat dengan dosis $0 \mathrm{ml}, 7,5 \mathrm{ml}, 15 \mathrm{ml}$.

Dari uji DMRT dapat dilihat pemberian amelioran tidak berpengaruh secara signifikan terhadap peningkatan kada hara Kalium. Pengaruh pemberian amelioran terhadap kadar hara Kalium (K) mengalami penurunan. Hal ini diduga karena pada pengukuran awal kadar K pada tanah reklamasi sudah sangat rendah sehingga bahan humat tidak dapat meningkatkan kadar hara Kalium (K).

Kadar K-tertukar tanah biasanya sekitar 0.5-0.6\% dari total K tanah. Ketersediaan K terkait dengan reaksi tanah dan Kejenuhan Basa $(\mathrm{KB})$, pada $\mathrm{pH}$ rendah (asam) dan $\mathrm{KB}$ rendah berarti juga ketersediaan K rendah. Nilai kritis K adalah 0.10me/100g tanah (Hanifah, 2005). 
Tabel 5. Pengaruh Bahan Amelioran terhadap Kadar Hara Kalsium (Ca)

\begin{tabular}{|c|c|c|c|}
\hline \multirow{2}{*}{ Dosis } & \multicolumn{3}{|c|}{ Variasi Media } \\
\cline { 2 - 4 } & T1S1 & T2S2 & T3S3 \\
\hline H1 & $0.975 \mathrm{abc}$ & $1.01 \mathrm{abc}$ & $0.935 \mathrm{abc}$ \\
\hline H2 & $0.795 \mathrm{ab}$ & $1.495 \mathrm{bc}$ & $0.87 \mathrm{abc}$ \\
\hline H3 & $0.945 \mathrm{abc}$ & $1.55 \mathrm{c}$ & $0.78 \mathrm{a}$ \\
\hline
\end{tabular}

Keterangan Angka yang diikuti oleh huruf yang sama pada kolom yang sama tidak berbeda nyata atau tidak signifikan menurut uji DMRT $(\operatorname{taraf} \alpha=5 \%)$. T1, T2, T3 = Tanah $100 \%, 50 \%, 75 \%$. S1,S2,S3 = Lumpur 0\%,50\%,25\%. H1,H2,H3= Humat dengan dosis $0 \mathrm{ml}, 7,5 \mathrm{ml}, 15 \mathrm{ml}$.

Pada perlakuan T1S1 dengan dosis 0ml (H1); T2S2 dengan dosis 7,5 ml (H2); dan T3S3 dengan dosis 7,5 ml (H2) mengalami penurunan. Hal ini di duga karena komposisi bahan amelioran rendah sehingga sulit meningkatkan kadar hara Ca. Pada uji DMRT penurunan dan peningkatan tidak berpengaruh secara signifikan.

Ketersediaan $\mathrm{Ca}$ dipengaruhi oleh $\mathrm{Mg}$. Pada prinsipnya $\mathrm{Ca}$ dan $\mathrm{Mg}$ mirip dengan $\mathrm{K}$, perbedaan hanya terletak pada fiksasi (perubahan unsur).Kedua unsur ini lebih lemah dibanding $\mathrm{K}$ sehingga bentuk ketiganya kation terlarut, kation tertukar, dan dalam mineral tanah (Hanifah, 2005).

Ketersediaan Ca dan Mg terkait dengan Kapasitas Tukar Kation (KTK) dan persen Kejenuhan Basa (KB). KB yang rendah mencerminkan kadar Ca dan Mg rendah. Jika dibandingkan, keterkaitan $\mathrm{Mg}$ pada situs kadar $\mathrm{Ca}$ tanah umumnya selalu lebih tinggi dibanding $\mathrm{Mg}$. Hal ini terkait dengan lebih besarnya Berat Atom (BA) Ca (= 40) dibanding Mg (=24) (Hanifah, 2005).

\section{B. Pengaruh Bahan Amelioran pada Pertumbuhan Tanaman Reklamasi}

Tabel 6. Pengaruh Bahan Amelioran terhadap Pertumbuhan Tinggi Tanaman Akasia

\begin{tabular}{|c|c|c|c|}
\hline \multirow{2}{*}{$\begin{array}{c}\text { Dosis H } \\
\text { (Asam Humat) }\end{array}$} & \multicolumn{3}{|c|}{ Variasi Media } \\
\cline { 2 - 4 } & T1S1 & T2S2 & T3S3 \\
\hline H1 & $2,5 \mathrm{ab}$ & $3,25 \mathrm{ab}$ & $2,75 \mathrm{ab}$ \\
\hline H2 & $3,0 \mathrm{ab}$ & $3,75 \mathrm{ab}$ & $4,0 \mathrm{~b}$ \\
\hline H3 & $2,15 \mathrm{ab}$ & $3,0 \mathrm{ab}$ & $2,0 \mathrm{a}$ \\
\hline
\end{tabular}

Keterangan Angka yang diikuti oleh huruf yang sama pada kolom yang sama tidak berbeda nyata atau tidak signifikan menurut uji DMRT ( $\operatorname{tar} a=5 \%$ ). T1, T2, T3 = Tanah $100 \%, 50 \%, 75 \%$. S1,S2,S3 = Lumpur 0\%,50\%,25\%. H1,H2,H3= Humat dengan dosis $0 \mathrm{ml}, 7,5 \mathrm{ml}, 15 \mathrm{ml}$.

Tabel 6 di atas menunjukkan bahwa bahan amelioran yang memiliki nilai pertumbuhan tinggi yang paling besar pada tanaman akasia merupakan perlakuan T3S3 dengan dosis $\mathrm{H} 2$ (7,5ml). Pada 
perlakuan T3S3 dengan dosis $\mathrm{H} 2(7,5 \mathrm{ml})$ terjadi perbedaan yang nyata dibandingkan dengan perlakuan media lainnya. Sedangkan pada perlakuan media lain selain perlakuan T3S3 dengan dosis $\mathrm{H} 2(7,5 \mathrm{ml})$ tidak memiliki perbedaan yang berbeda nyata diantara tiap-tiap perlakuan media tanam.

Jika dilakukan perbandingan untuk tiap-tiap perlakuan variasi medianya dapat terlihat bahwa pada dosis $\mathrm{H} 2$ (7,5ml) memiliki nilai yang paling tinggi pada masing-masing variasi media, baik pada variasi media T1S1, T2S2 dan juga T3S3. Sedangkan pada perlakuan dengan dosis H3 (15ml) memiliki nilai terendah pada masing-masing variasi media. Perlakuan media pada dosis tanpa asam humat H1 (0ml) masih memiliki nilai yang lebih baik dibandingkan dosis H3 (15ml).

Tabel 7. Pengaruh Bahan Amelioran Terhadap Pertumbuhan Tinggi Tanaman Sengon

\begin{tabular}{|c|c|c|c|}
\hline \multirow{2}{*}{$\begin{array}{c}\text { Dosis H } \\
\text { (Asam Humat) }\end{array}$} & \multicolumn{3}{|c|}{ Variasi Media } \\
\cline { 2 - 4 } & T1S1 & T2S2 & T3S3 \\
\hline H1 & $2,5 \mathrm{ab}$ & $3,5 \mathrm{ab}$ & $3,0 \mathrm{ab}$ \\
\hline H2 & $3,25 \mathrm{ab}$ & $3,0 \mathrm{ab}$ & $3,75 \mathrm{~b}$ \\
\hline H3 & $2,75 \mathrm{ab}$ & $3,5 \mathrm{ab}$ & $1,5 \mathrm{a}$ \\
\hline
\end{tabular}

Keterangan Angka yang diikuti oleh huruf yang sama pada kolom yang sama tidak berbeda nyata atau tidak signifikan menurut uji DMRT (taraf $\alpha=5 \%$ ). T1, T2, T3 = Tanah 100\%, 50\%, 75\%. S1,S2,S3 = Lumpur 0\%,50\%,25\%. H1,H2,H3= Humat dengan dosis $0 \mathrm{ml}, 7,5 \mathrm{ml}, 15 \mathrm{ml}$.

Dari tabel 7 di atas dapat dilihat bahwa data yang dihasilkan dari analisis statistik pertumbuhan tinggi tanaman Sengon menunjukkan bahwa tidak adanya pertumbuhan tinggi tanaman yang berubah secara signifikan. Pada perlakuan T3S3 dengan dosis H2 (7,5ml) dari tabel 7 dapat terlihat bahwa memiliki pertumbuhan tinggi tanaman Sengon yang paling besar nilainya. Pada variasi media T1S1 dan juga T3S3, dosis asam humat $\mathrm{H} 2$ (7,5ml) memiliki pengaruh yang jelas disbanding pada variasi media T2S2, dimana pada variai media ini dosis $\mathrm{H} 2(7,5 \mathrm{ml})$ kurang memiliki peran dalam menumbuhkan tinggi tanaman sengon. Dosis H2 (7,5ml) masih kurang efektif menumbuhkan tanaman dibandingkan dosis $\mathrm{H} 1(0 \mathrm{ml})$ dan juga dosis $\mathrm{H} 3(15 \mathrm{ml})$.

Walaupun bahan amelioran terlihat menumbuhkan tinggi tanaman sengon maupun akasia, akan tetapi pemberian bahan amelioran secara statistik tidak menunjukkan adanya perubahan secara signifikan dalam pertumbuhan tinggi tanaman akasiamaupun sengon. Dalam pertumbuhan tinggi tanaman akasia dan sengon memiliki persamaan pada pengaruh nyata terhadap pertumbuhan tinggi tanaman yang terjadi pada perlakuan media tanaman T3S3 dengan dosis $\mathrm{H} 2$ (7,5ml) dibanding dengan perlakuan media lainnya. Secara keseluruhan perlakuan media pada dosis humat H2 (7,5ml) 
memiliki peranan yang efektif dalam menaikkan pertumbuhan tanaman sengon maupun akasia, walaupun pertumbuhan yang terjadi tidak mengalami pertumbuhan secara signifikan.

Selain melihat pertumbuhan tinggi tanaman, pertumbuhan diameter tanaman Sengon dan Akasia juga dihitung pertumbuhan diameter tanaman Sengon maupun Akasia. Adapun data hasil dari analisis data statistik terlihat dari Tabel 8 dan Tabel 9 di bawah ini.

Tabel 8. Pengaruh Bahan Amelioran Terhadap Pertumbuhan Diameter Tanaman Akasia

\begin{tabular}{|c|c|c|c|}
\hline \multirow{2}{*}{$\begin{array}{c}\text { Dosis H } \\
\text { (Asam Humat) }\end{array}$} & \multicolumn{3}{|c|}{ Variasi Media } \\
\cline { 2 - 4 } & T1S1 & T2S2 & T3S3 \\
\hline H1 & $1,25 \mathrm{a}$ & $1,25 \mathrm{a}$ & $1,25 \mathrm{a}$ \\
\hline H2 & $1,25 \mathrm{a}$ & $1,0 \mathrm{a}$ & $1,25 \mathrm{a}$ \\
\hline H3 & $1,0 \mathrm{a}$ & $1,0 \mathrm{a}$ & $1,25 \mathrm{a}$ \\
\hline
\end{tabular}

Keterangan Angka yang diikuti oleh huruf yang sama pada kolom yang sama tidak berbeda nyata atau tidak signifikan menurut uji DMRT ( $\operatorname{taraf} \alpha=5 \%$ ). T1, T2, T3 $=$ Tanah $100 \%, 50 \%, 75 \%$. S1,S2,S3 = Lumpur $0 \%, 50 \%, 25 \%$. H1,H2,H3= Humat dengan dosis $0 \mathrm{ml}, 7,5 \mathrm{ml}, 15 \mathrm{ml}$.

Tabel 9. Pengaruh Bahan Amelioran terhadap Pertumbuhan Diameter Tanaman Sengon

\begin{tabular}{|c|c|c|c|}
\hline \multirow{2}{*}{$\begin{array}{c}\text { Dosis H } \\
\text { (Asam Humat) }\end{array}$} & \multicolumn{3}{|c|}{ Variasi Media } \\
\cline { 2 - 4 } H1 & T1S1 & T2S2 & T3S3 \\
\hline H2 & $1,25 \mathrm{a}$ & $1,25 \mathrm{a}$ & $1,25 \mathrm{a}$ \\
\hline H3 & $1,25 \mathrm{a}$ & $1,25 \mathrm{a}$ & $1,25 \mathrm{a}$ \\
\hline
\end{tabular}

Keterangan Angka yang diikuti oleh huruf yang sama pada kolom yang sama tidak berbeda nyata atau tidak signifikan menurut uji DMRT ( $\operatorname{taraf} \alpha=5 \%$ ). T1, T2, T3 $=$ Tanah $100 \%, 50 \%, 75 \%$. S1,S2,S3 = Lumpur $0 \%, 50 \%, 25 \%$. H1,H2,H3= Humat dengan dosis $0 \mathrm{ml}, 7,5 \mathrm{ml}, 15 \mathrm{ml}$.

Dari data hasil analisis statistik tersebut dapat dinyatakan bahwa bahan amelioran masih belum berpengaruh nyata dalam pertumbuhan diameter tanaman Sengon maupun Akasia. Dalam pertumbuhannya diameter tanaman hanya mengalami sedikit perubahan yang tidak secara signifikan perubahannya. Dalam pertumbuhan diameter tanaman sengon memiliki nilai stastistik yang sama dari semua medianya dan memiliki kelompok yang tidak berbeda.

Pertumbuhan diameter tanaman akasia dan sengon sulit untuk tumbuh cepat. Sulitnya pertumbuhan diameter tanaman pada Akasia bisa juga disebabkan kadar hara yang ada terikat untuk lebih menumbuhkan tinggi batang dan juga jumlah daun. Kadar hara memiliki peranan penting pada pertumbuhan tanaman. Seperti yang dituliskan Liferdi (2009) pada penelitiannya bahwa respon 
pemberian kadar hara lebih terlihat pada parameter tinggi, jumlah cabang, dan jumlah daun dibandingkan diameter batang tanaman. Terjadinya perbedaan respon tanaman pada pemberian kadar hara kemungkinan erat kaitannya dengan peranan kadar hara dalam pembentukan sel baru pada jaringan yang sedang tumbuh.

Pertumbuhan jumlah daun juga dihitung dalam penelitian kali ini. Pertumbuhan jumlah daun pada tanaman sengon dan akasia terjadi secara fluktuatif. Jika terjadi tumbuhnya daun baru pada minggu pertama tidak menutup kemungkinan adanya daun yang gugur pada minggu-minggu berikutnya dan bahkan jumlah daun yang gugur dapat melebihi daun yang tumbuh baru. Untuk memudahkan penafsiran dibuatlah data secara kualitatif. Data pertumbuhan jumlah tanaman Akasia dan Sengon dapat dilihat pada Tabel 10 dan Tabel 11 dibawah ini.

Tabel 10. Pengaruh Bahan Amelioran Terhadap Pertumbuhan Jumlah Daun Tanaman Akasia

\begin{tabular}{|c|c|c|c|}
\hline \multirow{2}{*}{$\begin{array}{c}\text { Dosis H } \\
\text { (Asam Humat) }\end{array}$} & \multicolumn{3}{|c|}{ Variasi Media } \\
\cline { 2 - 4 } H1 & T1S1 & T2S2 & T3S3 \\
\hline H2 & $2,0 \mathrm{a}$ & $2,0 \mathrm{a}$ & $2,25 \mathrm{a}$ \\
\hline H3 & $3,0 \mathrm{a}$ & $2,25 \mathrm{a}$ & $2,5 \mathrm{a}$ \\
\hline
\end{tabular}

Keterangan Angka yang diikuti oleh huruf yang sama pada kolom yang sama tidak berbeda nyata atau tidak signifikan menurut uji DMRT (taraf $\alpha=5 \%$ ). T1, T2, T3 $=$ Tanah $100 \%, 50 \%, 75 \%$. S1,S2,S3 = Lumpur 0\%,50\%,25\%. H1,H2,H3= Humat dengan dosis $0 \mathrm{ml}, 7,5 \mathrm{ml}, 15 \mathrm{ml}$

Tabel 11. Pengaruh Bahan Amelioran Terhadap Pertumbuhan Jumlah Daun Tanaman Sengon

\begin{tabular}{|c|c|c|c|}
\hline \multirow{2}{*}{$\begin{array}{c}\text { Dosis H } \\
\text { (Asam Humat) }\end{array}$} & \multicolumn{3}{|c|}{ Variasi Media } \\
\cline { 2 - 4 } H1 & T1S1 & T2S2 & T3S3 \\
\hline H2 & $2,25 \mathrm{a}$ & $2,5 \mathrm{a}$ & $2,5 \mathrm{a}$ \\
\hline H3 & $2,5 \mathrm{a}$ & $2,5 \mathrm{a}$ & $1,75 \mathrm{a}$ \\
\hline
\end{tabular}

Keterangan Angka yang diikuti oleh huruf yang sama pada kolom yang sama tidak berbeda nyata atau tidak signifikan menurut uji DMRT ( $\operatorname{tar} a f=5 \%$ ). T1, T2, T3 = Tanah $100 \%, 50 \%, 75 \%$. S1,S2,S3 = Lumpur $0 \%, 50 \%, 25 \%$. H1, H2,H3= Humat dengan dosis $0 \mathrm{ml}, 7,5 \mathrm{ml}, 15 \mathrm{ml}$.

Dari hasil analisis pertumbuhan jumlah daun pada tanaman sengon dan akasia terlihat bahwa pertumbuhan jumlah daun masih tidak terpengaruh secara signifikan oleh adanya bahan amelioran pada perlakuan media tanaman sengon maupun akasia. Dari hasil analisis statistik didapatkan data bahwa semua perlakuan media tanam akasia dan sengon memiliki kelompok yang sama yaitu kelompok a. Hasil analisis statistik diatas juga menunjukkan bahwa pada perlakuan T2S2 dengan 
dosis H3 (15ml) memiliki nilai terbesar baik itu pada tanaman akasia maupun sengon. Walaupun memiliki nilai statistik yang paling besar, tidak juga membuat pertumbuhan daun menjadi signifikan. Dari hasil penelitian juga menunjukkan bahwa kadar kalium miliki pengaruh paling dominan dalam pertumbuhan daun pada tanaman sengon maupun akasia, kadar hara kalium jugaterjadi peningkatan terbesar pada T2S2 dengan dosis H3. Pada pertumbuhan jumlah daun juga terjadi peningkatan paling besar pada perlakuan T2S2 dengan dosis H3 (15ml).

\section{Prospek Asam Humat dan Lumpur Instalasi Pengolahan Air Limbah (IPAL) Tambang Batubara sebagai Amelioran}

Setiap tahun lahan bekas tambang batubara yang akan direklamasi seluas 32,61 hektar. Hal ini mengacu pada kegiatan eksploitasi rata-rata luas penambangan pada area pertambangan batubara mencapai 32,61 hektar (Studi Kelayakan PT. BDMS).

Tabel 12. Pemanfaatan Lumpur untuk Lahan Reklamasi

\begin{tabular}{|c|c|c|c|c|c|c|}
\hline $\begin{array}{l}\text { Debit Air } \\
\text { Limbah }\end{array}$ & & npur & $\begin{array}{c}\text { Lahan } \\
\text { yang akan } \\
\text { di }\end{array}$ & $\begin{array}{c}\text { Lumpur yang } \\
\text { digunakan }\end{array}$ & $\begin{array}{c}\text { Penggunaan } \\
\text { Lumpur } \\
\text { dalam }\end{array}$ & $\begin{array}{c}\text { Efisiensi } \\
\text { Lumpur } \\
\text { dalam }\end{array}$ \\
\hline $\mathbf{M}^{3} /$ hari & $M^{3} /$ hari & $M^{3} /$ tahun & (ha) & $\left(M^{3} / \mathbf{h a}\right)$ & $\left(\mathbf{M}^{3}\right)$ & $(\%)$ \\
\hline 1 & 2 & 3 & 4 & $5=0.25^{1)} * 625^{2)}$ & $6=5 * 4$ & $7=(6 / 3) * 100$ \\
\hline 4000 & 40 & 14600 & 32.61 & 156.25 & 5095.31 & 34.90 \\
\hline
\end{tabular}

Keterangan: 1). $25 \%$ lumpur yang digunakan untuk 1 (satu) lubang tanam.

2). Dalam 1 (satu) hektar terdapat 625 lubang tambang.

Timbulan lumpur yang dihasilkan dalam setahun mencapai $14.600 \mathrm{~m}^{3}$ dari proses Instalasi Pengolahan Air Limbah (IPAL). Dari timbulan lumpur tersebut dapat dimanfaatkan dalam reklamasi lahan bekas tambang batubara dengan kebutuhan lumpur sebesar $156,25 \mathrm{~m}^{3} /$ hektar. Dalam setahun luas lahan yang direklamasi rata-rata seluas 32,61 hektar. Dari luas lahan tersebut dapat dimanfaatkan lumpur Instalasi Pengolahan Air Limbah (IPAL) sebanyak 35\% dari total keseluruhan timbulan lumpur $14.600 \mathrm{~m}^{3}$. Pemanfaatan lumpur tersebut juga dapat mereklamasi lahan dalam setahun dengan menimalisir penggunaan top soil sebesar $25 \%$ dari total keseluruhan keperluan top soil untuk mereklamasi lahan seluas 32,61 hektar setiap tahunnya. Dengan asumsi dosis asam humat yang digunakan sebanyak 562,5 liter/hektar. 
Dari pemanfaatan lumpur Instalasi Pengolahan Air Limbah (IPAL) tambang batubara dapat mengurangi dampak pencemaran lingkungan yang diakibatkan oleh lumpur Instalasi Pengolahan Air Limbah (IPAL) tambang batubara. Pemanfaatan lumpur dapat digunakan sebagai media pengganti top soil pada lahan reklamasi. Penggunaan lumpur sebagai pengganti media tanam dapat meminimalisir penggunaan top soil hingga 25\%. Selain itu penggunaan lumpur Instalasi Pengolahan Air Limbah (IPAL) sebagai bahan media tanam yang dikombinasikan dengan tanah top soil dan asam humat dapat memperbaiki sifat dan karakteristik tanah bekas tambang batubara yang akan digunakan untuk lahan reklamasi.

\section{KESIMPULAN DAN SARAN}

\section{Kesimpulan}

Dari penelitian yang telah dilakukan maka dapat diambil kesimpulan sebagai berikut:

1. Pemberian asam humat dan lumpur Instalasi Pengolahan Air Limbah (IPAL) tambang batubara dapat meningkatkan kadar hara dan mempengaruhi pertumbuhan tanaman reklamasi namun tidak berpengaruh secara signifikan, pada kadar hara N-Total perlakuan T1S1H2 dan T1S1H3 mengalami kenaikan 12,5\%, T2S2H2 9,09\% dan T3S3H3 10\%. Pada kadar hara P-Tersedia perlakuan T2S2H2 mengalami kenaikan 75\%. Pada kadar hara Kalsium perlakuan T2S2H1 megalami kenaikan 29,55\%, T1S1H2 48,44\%, T2S2H3 106,93\%, dan T3S3H3 29,41\%. Pada kadar hara Kalium perlakuan T2S2H3 mengalami kenaikan 55,56\%. Kenaikan N-Total mengalami perubahan yang signifikan sedangan kadar hara P-Tersedia, Kalsium, dan Kalium tidak signifikan namun dapat berpotensi sebagai pengganti top soil pada lahan bekas tambang batubara.

2. Terdapat interaksi bahan amelioran antara asam humat dan lumpur Instalasi Pengolahan Air Limbah (IPAL) tambang batubara dalam meningkatkan kadar hara dan pertumbuhan tanaman Akasia dan Sengon.

3. Pemberian asam humat dan lumpur Instalasi Pengolahan Air Limbah (IPAL) membantu meningkatkan pertumbuhan tanaman. Pada pertumbuhan tinggi tanaman terdapat variasi media T3S3 dengan dosis $\mathrm{H} 2$ (7,5ml) baik Sengon maupun Akasia yang memiliki peningkatan tinggi tanaman sebesar $16,1 \%$ dengan hasil uji statistik bernilai 4,0b pada tanaman sengon dan $18 \%$ dengan nilai hasil uji statistik sebesar 3,75b pada tanaman Sengon Akasia, pada variasi ini merupakan variasi paling efektif pertumbuhannya. Pada pertumbuhan diameter tanaman tidak 
menunjukkan pertumbuhan yang sangat signifikan karena kadar hara yang terdapat pada tanaman lebih menumbuhkan tinggi batang dan juga jumlah daun. Sedangkan pada petumbuhan jumlah daun terdapat variasi media T2S2 dengan dosis $\mathrm{H} 3(15 \mathrm{ml})$ yang merupakan variasi paling efektif pertumbuhannya dilihat dari hasil uji statistik rata-rata dengan nilai 3,0a pada tanaman Akasia dan 2,75a pada tanaman Sengon.

\section{Saran}

Diperlukan penelitian lebih lanjut dengan dosis bahan amelioran asam humat dan lumpur Instalasi Pengolahan Air Limbah (IPAL) tambang batubara yang berbeda. Seperti dosis asam humat yang lebih tinggi dan interval dosis yang lebih kecil untuk peningkatan kadar hara dalam pertumbuhan tanaman reklamasi.

\section{DAFTAR PUSTAKA}

Hanifah, Kemas Ali. 2005. Dasar - Dasar Ilmu Tanah. Rajagrafindo Persada. Jakarta.

Liferdi,L. 2009. Analisis Jaringan Daun sebagai Alat untuk Menetukan Status Hara Fosfor pada Tanaman Manggis. Balai Penelitian Tanaman Buah Tropika. Solok.

Tan, K.H. 1991. Dasar- Dasar Kimia Tanah. Gadjah Mada University Press. Yogyakarta

Studi Kelayakan PT. Baradinamika Mudasukses (BDMS)

Wibowo, A.Y. 2011. Pengaruh Abu Terbang dan Bahan Humat Terhadap Pertumbuhan Tanaman Sengon (Peraserienthes falcataria) dan Sifat-sifat Kimia Tanah di Lahan Bekas Tambang Batubara. Tesis. Institut Pertanian Bogor 